\title{
Effect of cattle manure on sunflower production and water use in two types of soil ${ }^{1}$
}

\author{
Francisco das Chagas Fernandes Maia Filho², Evandro Franklin de Mesquita ${ }^{3}$, Hugo Orlando Carvallo Guerra \\ Mácio Farias Moura ${ }^{5}$ Lúcia Helena Garófalo Chaves ${ }^{6}$
}

\begin{abstract}
The aim of the present study was to evaluate water consumption, use efficiency and yield components of sunflower variety Embrapa 122 V/2000 cultivated in two types of soil (Fluvissol and Haplic Luvisol) subjected to increasing doses of cattle manure. The experiment was carried out in a greenhouse at Universidade Estadual da Paraíba. The experimental design was completely randomized in a factorial scheme. The irrigation was performed every other day, replacing the water absorbed by the plants. The water consumption and the use efficiency were evaluated, being the use efficiency determined by the ratio of the total dry mass of sunflower and the amount of water used to produce it in each treatment. Plants were harvested at 95 days after sowing when the following parameters were evaluated: number of seeds per plant, weight of seeds per plant, weight of 1000 seeds and the outer diameter of the capitulum (head). The results showed that the sunflower was positively affected by cattle manure application, increasing the production components and the water use efficiency, regardless of the type of soil. Excepting for the 1000 seeds weight and the water use efficiency, the type of soil affected significantly the water use, the number and weight of seeds per plant. The plants cultivated in Haplic Luvisol had a better performance.
\end{abstract}

Key words: Helianthus annuus, organic fertilization, production.

\section{RESUMO}

\section{Efeito do esterco bovino no consumo de água e produção de girassol em dois tipos de solos}

O objetivo deste trabalho foi avaliar o consumo, a eficiência do uso da água e os componentes de produção do girassol, variedade Embrapa 122 V/2000, em dois tipos de solos: Neossolo Flúvico e Luvissolo Háplico, quando submetidos a doses crescentes de esterco bovino. O experimento foi desenvolvido em uma estufa agrícola da Universidade Estadual da Paraíba. O delineamento experimental utilizado foi o inteiramente casualizado, em esquema fatorial. A irrigação foi realizada a cada dois dias, repondo a água consumida. Foi computado o consumo de água do girassol, bem como sua eficiência de uso, esta última determinada pela relação entre a massa seca total de girassol e o volume de água utilizado para produzir essa massa, em cada tratamento. A colheita foi feita aos 95 dias após semeadura, quando o número e a massa de sementes por planta, a massa de 1000 sementes e o diâmetro externo do capítulo foram determinados. Os resultados mostram que o girassol foi afetado positivamente pela aplicação de esterco bovino, que

\footnotetext{
Received: 10/07/2012; Accpted: 05/04/2013

Article extracted from the fisrt author's monography.

2 Graduate in Agricultural Science. Departamento de Engenharia Agrícola, Universidade Federal de Campina Grande, Avenida Aprígio Veloso, 882, 58429-140, Campina Grande, Paraíba, Brasil. juniormaiapb@yahoo.com.br

${ }^{3}$ Agronomist engineer, Doctor of Science. Departamento de Ciências Agrárias e Exatas, Universidade Estadual da Paraíba, Escola Agrotécnica do Cajueiro, Campus IV, Zona Rural, 58884-000, Catolé do Rocha, Paraíba, Brasil. elmesquita4@uepb.edu.br (corresponding author).

${ }^{4}$ Agricultural engineer, Doctor of Science. Departamento de Engenharia Agrícola, Universidade Federal de Campina Grande, Avenida Aprígio Veloso, 882, 58429-140, Campina Grande, Paraíba, Brasil. hugo_carvallo@ hotmail.com

${ }^{5}$ Agronomist engineer, Doctor of Science. Departamento de Ciências Agrárias, Universidade Federal Rural de Pernambuco, Unidade Acadêmica de Garanhuns, Avenida Bom Pastor, s/n, Boa Vista, 55292-270, Garanhuns, Pernambuco, Brasil. maciof@yahoo.com.br

${ }^{6}$ Agronomist engineer, Doctor of Science. Departamento de Engenharia Agrícola, Universidade Federal de Campina Grande, Avenida Aprígio Veloso, 882, 58429-140, Campina Grande, Paraíba, Brasil. lhgarofalo@hotmail.com
} 
acarretou aumento dos componentes da produção e da eficiência no uso da água, independentemente do tipo de solo. Com exceção da massa de 1000 sementes e da eficiência do uso da água, o tipo de solo afetou significativamente o consumo de água do girassol e o número e a massa de sementes por planta. As plantas cultivadas no Luvissolo Háplico tiveram melhor comportamento.

Palavras-chave: Helianthus annuus L., adubação orgânica, produção.

\section{INTRODUCTION}

The sunflower (Helianthus annuus L.) is an oilseed annual crop from dicotyledonous class. It is native from the North American continent (Pearson et al., 2010), and has been widely used in many countries for edible oil production when compared to other oilseeds (Vazin et al., 2011). The oil present in sunflower achenes has high quality for human consumption and can be used to produce biodiesel (Lazzarotto et al., 2005). In some parts of Paraiba State, especially in the hinterland, the sunflower crops have been presenting low productivity, due to the use of traditional cultivars with low productive capacity and the lack of an appropriate mineral nutrition program.

Most of the Brazilian semiarid soils are characterized by the low availability of nitrogen and phosphorus, and this failure is usually corrected by using high doses of mineral fertilizers (Menezes \& Oliveira, 2008), which is considered an economically and environmentally unsatisfactory solution. For these reasons, the search for alternative sources of fertilizer has increased, which are less harmful to the environment and economically efficient at the same time. Thus, to produce sunflower in semi-arid climate, it is necessary to seek for alternatives that regard the need of obtaining high productivity at a low cost, while using organic sources in a rational way, reducing the environmental impacts of agriculture.

Currently, there are several sources of organic fertilizers used in agriculture, but cattle manure has the greatest potential for fertilization, especially in small farms of Paraiba hinterland. However, there isn't much information about the quantities to be used in sunflower crop in order to obtain a compensatory income.

There are a few studies related to this topic in Brazil. Nobre et al. (2010), working with four levels of cattle manure $(0,0.7,1.4$ and $2.1 \%$ based on the dry matter) on sunflower variety Embrapa 122 V/200, observed that the fertilization anticipated the flowering and had positive effect of on growth.

Therefore, the objective of the present study was to evaluate the effects of cattle manure fertilization on consumption, water use efficiency and yield components of sunflower variety Embrapa 122 V/2000, cultivated in two types of soil.

\section{MATERIAL AND METHODS}

The experiment was carried out from November 2010 to February 2011, in a greenhouse at the Center for Agricultural and Human Sciences, Universidade Federal da Paraíba, Campus IV, Catolé do Rocha - PB, referenced by geographic coordinates: latitude $6^{\circ} 20$ ' 38 "South, longitude $37^{\circ} 44^{\prime} 48^{\prime \prime}$ West and altitude of $275 \mathrm{~m}$.

Two types of soil, Fluvissol and Haplic Luvisol, collected respectively at the municipalities of Catolé do Rocha and Brejos dos Santos, Paraíba State, were used as substrates in the experiment. The samples were collected at 0-20 cm depth, air-dried, sieved through $2.0 \mathrm{~mm}$ mesh, and chemically and physically characterized according to Embrapa (1997), and the results are presented in Table 1.

The experimental design was completely randomized and the treatments were arranged in a factorial scheme (2 $\mathrm{x} 4$ ) +2 , consisting of two soil types (Fluvissol - Soil 1, Haplic Luvissol - Soil 2), and four doses of cattle manure $(5,10,15$ and $20 \% \mathrm{v} / \mathrm{v})$, plus two additional witnesses, which consisted of each soil, chemically fertilized according to the recommendation, with three replicates, totalizing 30 experimental units. Each experimental unit consisted of a plastic container with $30 \mathrm{~L}$ capacity with one plant of sunflower (Helianthus annuus L.) variety Embrapa 122/V-2000.

The cattle manure used as treatments were previously tanned and mixed to the soil in the following proportions: $5 \%$ (1.5 L of manure $+28.5 \mathrm{~L}$ of soil), $10 \%$ (3 L of manure + $27 \mathrm{~L}$ of soil), $15 \%$ (4.5 L of manure $+25.5 \mathrm{~L}$ of soil) and $20 \%$ ( $6 \mathrm{~L}$ of manure $+24 \mathrm{~L}$ of soil). According to the soil analyzes, the witnesses were chemically fertilized with 40-70-30 kg ha $^{-1}$ of N-P $\mathrm{O}_{5}-\mathrm{K}_{2} \mathrm{O}$ (Ribeiro et al., 1999).

Before sowing, the water content in both soils was brought to field capacity. The equation to calculate the planting irrigation (Albuquerque, 2010) was:

$$
\mathrm{I}=(\mathrm{FC}-\mathrm{UA}) \mathrm{xd} \times \mathrm{D},
$$

Where:

I : Irrigation depth (mm);

FC : Water content in soil at field capacity (\% weight);

UA : Water content in soil at the irrigation day (\% weight);

$\mathrm{d}:$ Bulk density $\left(\mathrm{g} / \mathrm{cm}^{3}\right)$; 


\section{D : Soil depth $(\mathrm{cm})$.}

The following irrigations were performed every two days, according to the amount of water used by the crop. The volume of each irrigation was calculated every day by monitoring the water content of the soil with a TDR (Time Domain Reflectometry) probe PR2 Model at four depth intervals: 0 - 10, 10 - 20, 20 - 30 and $30-40 \mathrm{~cm}$, using the equation of Albuquerque (2010), previously presented. These values were set in a spreadsheet program, which counted the daily water content of each of the four layers of the soil profile.

The sowing was carried out on November 15, 2010, at $5 \mathrm{~cm}$ depth, with seven seeds per pot, distributed equidistantly. Seedling emergence began on the fourth day after sowing (DAS) and continued until the fourteenth. The thinning was performed at $20 \mathrm{DAS}$, leaving one plant per pot, i.e., the most vigorous.

The irrigation was suspended at $95 \mathrm{DAS}$, regarding to the physiological maturity of the grain, i.e., when the grains presented hard mass (Silva et al., 2007). At the same time, the whole crop was at growth stage R9 (head tilted down, with back and bracts showing color between yellow and brown).

During the experiment, the weeds control, the soil surface scarifying and the plants stalking were manually performed, while preventive sprays were applied every 15 days in a conventional manner.

At harvesting, the head of each plant was cut and immediately placed in a plastic bag, which was sealed. Thus, the outer diameter of the head was measured, the number of seeds per plant counted and weighed, determining the weight of 1000 seeds.

The amount of water consumed by the plants in volume and the cumulative consumption were also assessed, and the consumption efficiency was determined by the ratio between the weight of the total dry matter and the volume of water used in each treatment, according to the methodology described by Gardner et al. (1985) and Barker et al. (1989). The total dry matter (leaf, stem, head and root) was weighed with a precision balance after drying in an oven with forced air at $65^{\circ} \mathrm{C}$ until obtaining constant weight.

The statistical analyzes were performed through the computer program SAEG 5.0 (SAEG, 2003), however the Dunnett test at $5 \%$ probability was performed using the program SAS 9.0. (Gomes, 2009).

\section{RESULTS AND DISCUSSION}

The yield components of sunflower variety Embrapa 122-V2000, were influenced, at $1 \%$ probability, by cattle manure and the soil types. The water consumption for different levels of manure, the weight of 1000 seeds and the efficiency of water use for the types of soils were not affected by the treatments (Table $2)$. It was also observed that there was no significant interaction between treatments on any variable studied. However, considering that the isolated factors, soil and cattle manure, presented significant effects, it was decided to perform the deployment of the interaction according to Sampaio (1998), which says that, the F

Table 1. Physical and chemical characterization of the two types of soil and of the cattle manure

\begin{tabular}{|c|c|c|c|}
\hline Chemical charactersitics & Fluvissol & Haplic Luvissol & Cattle manure \\
\hline $\mathrm{pH}$ & 6.00 & 6.60 & 7.70 \\
\hline $\mathrm{Ca} \quad\left(\mathrm{cmol}_{\mathrm{c}} \mathrm{kg}^{-1}\right)$ & 2.34 & 3.66 & 7.70 \\
\hline $\operatorname{Mg}\left(\mathrm{cmol}_{\mathrm{c}} \mathrm{kg}^{-1}\right)$ & 2.41 & 2.33 & 15.90 \\
\hline $\mathrm{Na}\left(\mathrm{cmol}_{\mathrm{c}} \mathrm{kg}^{-1}\right)$ & 0.02 & 0.06 & 9.18 \\
\hline $\mathrm{K} \quad\left(\mathrm{cmol}_{\mathrm{c}} \mathrm{kg}^{-1}\right)$ & 0.33 & 0.72 & 0.06 \\
\hline $\mathrm{H} \quad\left(\mathrm{cmol}_{\mathrm{c}} \mathrm{kg}^{-1}\right)$ & 0.00 & 0.06 & 0.00 \\
\hline Al $\quad\left(\mathrm{cmol}_{\mathrm{c}} \mathrm{kg}^{-1}\right)$ & 0.00 & 0.00 & 0.00 \\
\hline $\mathrm{P} \quad\left(\mathrm{cmol}_{\mathrm{c}} \mathrm{kg}^{-1}\right)$ & 18.30 & 21.90 & 56.00 \\
\hline $\mathrm{MO}\left(\mathrm{g} \mathrm{kg}^{-1}\right)$ & 8.10 & 5.30 & - \\
\hline \multicolumn{4}{|l|}{ Physical characteristics } \\
\hline Sand & 64.00 & 52.50 & - \\
\hline Silt & 20.60 & 42.50 & - \\
\hline Clay & 15.40 & 5.10 & - \\
\hline Bulk density $\quad\left(\mathrm{g} \mathrm{dm}^{-3}\right)$ & 1.54 & 1.28 & - \\
\hline Particle density $\left(\mathrm{g} \mathrm{dm}^{-3}\right)$ & 2.68 & 2.67 & - \\
\hline Total porosity $\quad(\%)$ & 42.54 & 52.05 & - \\
\hline Field capacity $\quad(\%, v / v)$ & 17.00 & 22.80 & - \\
\hline Wilting point $\quad(\%, \mathrm{v} / \mathrm{v})$ & 5.83 & 6.97 & - \\
\hline Available water $(\%, v / v)$ & 11.17 & 15.83 & - \\
\hline
\end{tabular}


test showed that the average change in the interaction between treatments was not wide enough compared to the variance of the error.

According to the results of the analysis of variance (ANOVA), types of soil affected significantly ( $p<0.01$ ) the water consumption (Table 2). Meanwhile, the doses of cattle manure caused a significant effect only on the water use efficiency.

The regressions for the quantitative factor cattle manure, regarding to the number of seeds per sunflower plant, can be observed in Figure 1, presenting quadratic trend for Fluvissol (Soil 1) and linear increase for the Haplic Luvisol (Soil 2). It was observed that the growth of the plants cultivated in Soil 1 was positively affected to the increase of the doses of manure, reaching the maximum of 1126 seeds at $18.23 \%$, in a quadratic behavior. On the other hand, the number of seeds per plant cultivated in Soil 2 had a linear behavior with the increase of 27.79 seeds per percentage unit of manure increased in the soil, totalizing 1428 seeds per plant with the dose of $20 \%$.

These results showed better soil efficiency with 20 and $18 \%$ of cattle manure for soils 2 and 1, respectively, corroborating with the results obtained by Mielniczur \& Bayer (2008), who said that organic matter is a key component of the productive capacity of the soils, due to their effects on nutrient availability, capacity of cation exchange, toxic elements and micronutrients complexation and water retention and infiltration.
From the results, it is clear that the Haplic Luvisol is $26.68 \%$ superior, as a result of the higher levels of phosphorus, potassium and calcium present in this type of soil, as evidenced by Braz \& Rossetto (2010), who obtained the following order of nutrients accumulation on dry matter of sunflower Embrapa 111 V/2000: N > K > $\mathrm{Ca}>\mathrm{P}$ with the respective levels $112>74>56>51 \mathrm{~g} \mathrm{~kg}^{-1}$, demonstrating the high extractions of these nutrients in the soil.

Biscarro et al. (2008), working with irrigated crop of sunflower cultivar H 358 Dekalb, obtained 707 seeds per plant, in Cassilândia, MS, fertilizing with $52.6 \mathrm{~kg} \mathrm{~N} \mathrm{ha}^{-1}$. Nobre et al. (2010) obtained 571 seeds per plant of sunflower variety Embrapa 122 V/2000 irrigated with wastewater, and fertilized with cattle manure. The number of seeds obtained in this present study were higher than those observed by these authors, and the values indicate that, besides of improving the physical, chemical and biological properties of the soils, the cattle manure possibly was the responsible for providing the higher amount of nutrient for the crop development.

As the manure level in both soils increased, the seed weight per plant increased linearly with $0.56 \mathrm{~g}$ and $1.07 \mathrm{~g}$ for each percentage unit of manure dose in Fluvissol (Soil 1) and Haplic Luvisol (Soil 2), respectively, reaching the peak of 27.17 g plant $^{-1}$ (Soil 1) and 36.26 g plant $^{-1}$ (Soil 2), corresponding to the highest dose of manure (Figure 2). The better response was observed at dose $20 \%$, which

Tabela 2. Analysis of variance for the production and consumption components and water use efficiency in sunflower variety Embrapa 122-V2000: number of seeds per plant (NSP), weight of seeds per plant (WSP), weight of 1000 seeds (W1000S), outer diameter of the head (EDH), water consumption (WC) and water use efficiency (WUE)

\begin{tabular}{|c|c|c|c|c|c|c|c|}
\hline \multirow{2}{*}{$\begin{array}{l}\text { Source of } \\
\text { variation }\end{array}$} & \multirow{2}{*}{ GL } & \multicolumn{5}{|c|}{ SQUARE MEAN } & \multirow[b]{2}{*}{ WUE } \\
\hline & & NSP & WSP & W1000S & EDH & WC & \\
\hline Soils (S) & 1 & $272214.00^{* *}$ & $166.90^{* *}$ & $0.33^{* *}$ & $22.04^{* *}$ & $2153.10^{* *}$ & $0.20^{\mathrm{ns}}$ \\
\hline Doses (D) & 3 & $95976.00^{* *}$ & $182.73^{* *}$ & $0.67^{\text {ns }}$ & $15.51^{* *}$ & $214.20^{\mathrm{ns}}$ & $0.23^{* *}$ \\
\hline$S * D$ & 3 & 79924.00 ns & 19.97 ns & $0.30^{\mathrm{ns}}$ & $3.58^{\mathrm{ns}}$ & $163.00 \mathrm{~ns}$ & 0.12 ns \\
\hline Doses/ S1 & (3) & & & & & & \\
\hline linear effect & 1 & $115544.00^{* *}$ & $118.00^{* *}$ & $0.67^{* *}$ & $10.66^{* *}$ & - & $0.68^{* *}$ \\
\hline quadratic effect & 1 & $0.75^{* *}$ & $8.00^{\mathrm{ns}}$ & $1.56^{\mathrm{ns}}$ & $7.20^{* * *}$ & - & $0.29 \mathrm{E}-06^{\mathrm{ns}}$ \\
\hline Lack of fit & 1 & 121410.00 ns & $10.25^{\mathrm{ns}}$ & $0.70^{\mathrm{ns}}$ & $0.40^{\mathrm{ns}}$ & - & $0.14 \mathrm{E}-08$ ns \\
\hline Doses/ S2 & (3) & & & & & & \\
\hline linear effect & 1 & $175068.00^{* *}$ & $431.00^{* *}$ & - & $697.40^{* *}$ & - & - \\
\hline quadratic effect & 1 & $660.00^{\mathrm{ns}}$ & $0.60^{\mathrm{ns}}$ & - & $19.86^{\mathrm{ns}}$ & - & - \\
\hline Lack of fit & 1 & $115019.00 \mathrm{~ns}$ & 38.89 ns & - & $0.22 \mathrm{~ns}$ & - & - \\
\hline Residue & 16 & & & & & & \\
\hline Test S1 vs Factorial & 1 & $227760.00^{\mathrm{ns}}$ & 75.27 ns & $0.72^{\mathrm{ns}}$ & $17.79^{\text {ns }}$ & 8.74 ns & $0.02^{\mathrm{ns}}$ \\
\hline Test S2 vs Factorial & 1 & $86320.00^{\text {ns }}$ & $574.64^{* *}$ & $1.48^{\mathrm{ns}}$ & $23.73^{\mathrm{ns}}$ & $736.54^{* *}$ & $0.02^{\text {ns }}$ \\
\hline extra residue & 4 & $49544.37^{* *}$ & $48.74^{* *}$ & $0.26^{* *}$ & $3.16^{* *}$ & $22.32^{* *}$ & $0.01^{* *}$ \\
\hline $\mathrm{CV}(\%)$ & & $13.95^{* *}$ & $14.22^{* *}$ & $20.05^{* *}$ & $5.07^{* *}$ & $9.51^{* * *}$ & $7.71^{* *}$ \\
\hline
\end{tabular}

Significant at $0,05(*)$ and at 0,01 (**) of probability; (ns) not significant; - GL - degree of freedom; CV - Coefficient of variation; S1= Fluvissol; S2= Haplic Luvissol, Teste = treatment chemically fertilized, factorial = treatments fertilized with cattle manure. 
appears to be a beneficial effect of manure, as it corrects the nutritional deficiency in both soils. It was observed that the number of seeds was proportional to the seeds weight per plant (Figure 1), especially on Haplic Luvisol (Soil 2), which presented the highest values as a result of the nutrients availability, containing 56.4, 19.67 and 118.18 $\%$ more calcium, phosphorus and potassium, respectively, than the Fluvissol (Soil 1). The results presented above were lower than the $44.61 \mathrm{~g} \mathrm{plant}^{-1}$ observed by Nobre $e t$ al. (2010), irrigating with $120 \%$ of the available water and fertilizing with cattle manure.

The mass of 1000 seeds increased linearly, according to the increase of the doses of cattle manure, regardless to the type of soil (Figure 3). The increase in the weight of 1000 seeds was $0.66 \mathrm{~g}$ per percentage unit of cattle manure added to the soil, reaching the maximum weight of $30.63 \mathrm{~g}$, when fertilized with the highest dose of manure. From the results, it is clear that the plants produced many seeds per plant (Figure 1), however, the sizes were below than expected for this variety, reflecting on the low weight of seeds per plant and on the weight of 1000 seeds (Figures 2 and 3). This occurrence may be associated to the nitrogen deficiency visually observed at production stage. During this stage, the occurrence of fails in the filling or even the absence of achenes in the center of the sunflower head are very common. Those events can be attributed to the greater demand for assimilates from achenes of the flowers firstly pollinated (Castro \& Farias, 2005). The test results were below the average weights of $59.7 \mathrm{~g} / 1000$ seeds, observed by Silva et al. (2009) while studying three sunflower hybrids (Agrobel 960, 251 and Helio BRHS 5) under two spacings (70 and $90 \mathrm{~cm}$ ), and than $71.57 \mathrm{~g} /$

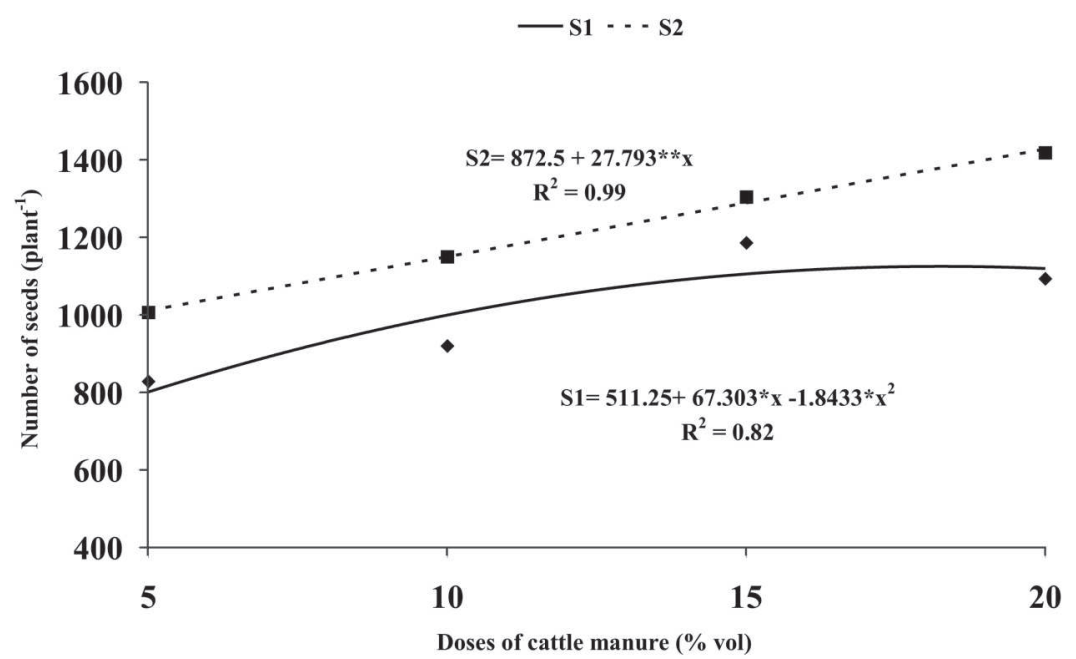

Figure 1. Number of seeds per plant of sunflower variety Embrapa 122-V2000 according to the doses of cattle manure applied to the soil (Fluvissol-S1, Haplic Luvisol-S2) (*P<0,05; ** $\mathrm{P}<0,01)$.

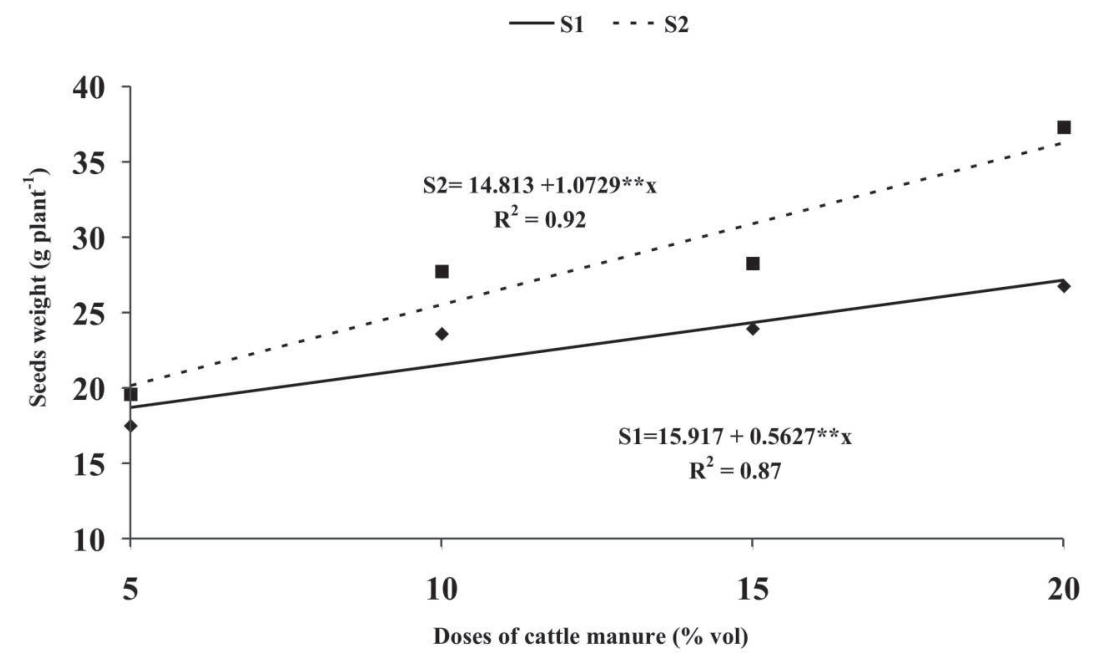

Figure 2. Weight of seeds per planto f sunflower variety Embrapa 122-V2000 according to the doses of cattle manure applied on the soil (Fluvissol-S1, Haplic Luvisol-S2) ( $\left.{ }^{\mathrm{P}}<0,05 ; * * \mathrm{P}<0,01\right)$. 
1000 seeds, observed by Silva et al. (2011), when provided $533.7 \mathrm{~mm}$ of water during the cycle of Sunflower variety Embrapa 122 V/2000. The lower values obtained in this study may be due to the difference of the climatic conditions, genotypes, irrigation management and fertilizer, among other factors.

The values of the outer diameter of the head were adjusted to the quadratic model, and presented an increase behavior, reaching the maximum of $16 \mathrm{~cm}$ when the dose of manure was $15.22 \%$. After this point, the diameter gradually decreased with the increase of the dose of manure on Fluvissol (Soil 1) (Figure 4). For Haplic Luvisol (Soil 2), the diameter of the head was adjusted to the increasing linear model with addition of $0.30 \mathrm{~g}$ per percentage unit increased of cattle manure, reaching the value of $19.66 \mathrm{~cm}$ when fertilized with $20 \%$ of the manure. This value is in accordance with the number of seeds per plant (Figure 1), as the larger is the diameter of the head, the greater is the amount of seeds it is expected to hold. According to Lobo \& Grassi Filho (2007), the diameter of the head has direct implications on the potential number of achenes, which is the essential component of productivity. The values of the diameter of the head observed on this sunflower variety were lower than those obtained by Nobre et al. (2010), similar to those obtained by Silva et al. (2011) and higher than those observed by Silva et al. (2009), Junior Santos et al. (2011) and Joner et al. (2011). These differences may be related to the differences on the climatic conditions, environments, genotypes, irrigation management and fertilization. Among the several techniques of growing sunflower, choosing the appropriate genotype is the most important step of the production system.

With the objective of comparing the components of sunflower production obtained with manure with those

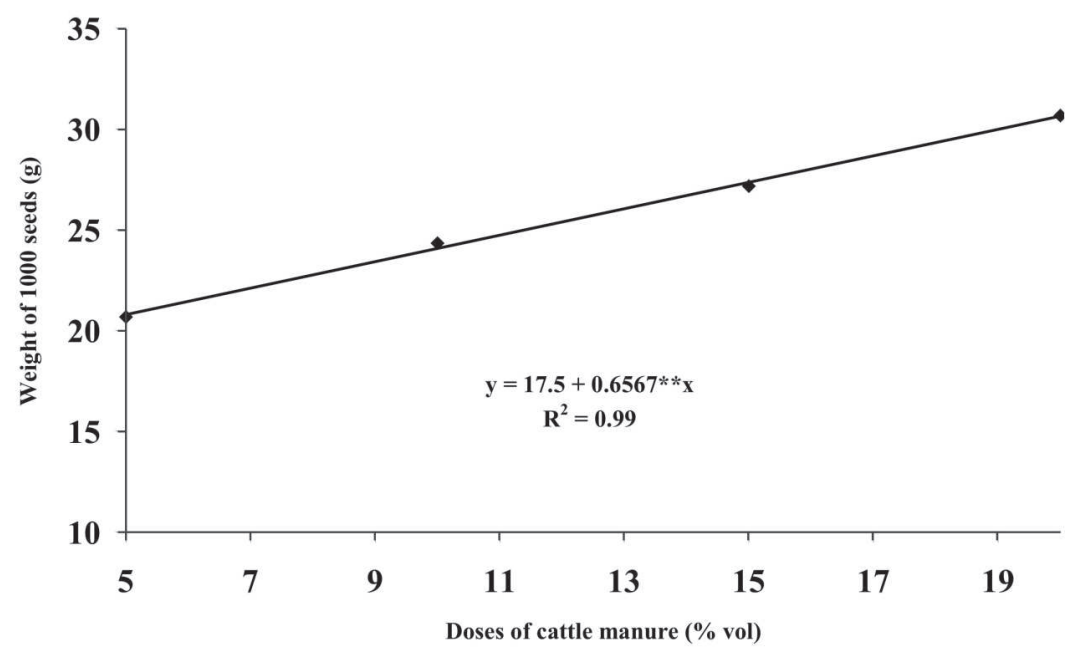

Figura 3. Weight of 1000 seeds ( $\mathrm{g}$ ) of sunflower var. Embrapa 122-V2000 according to the doses of cattle manure applied $(* * \mathrm{P}<0,01)$.

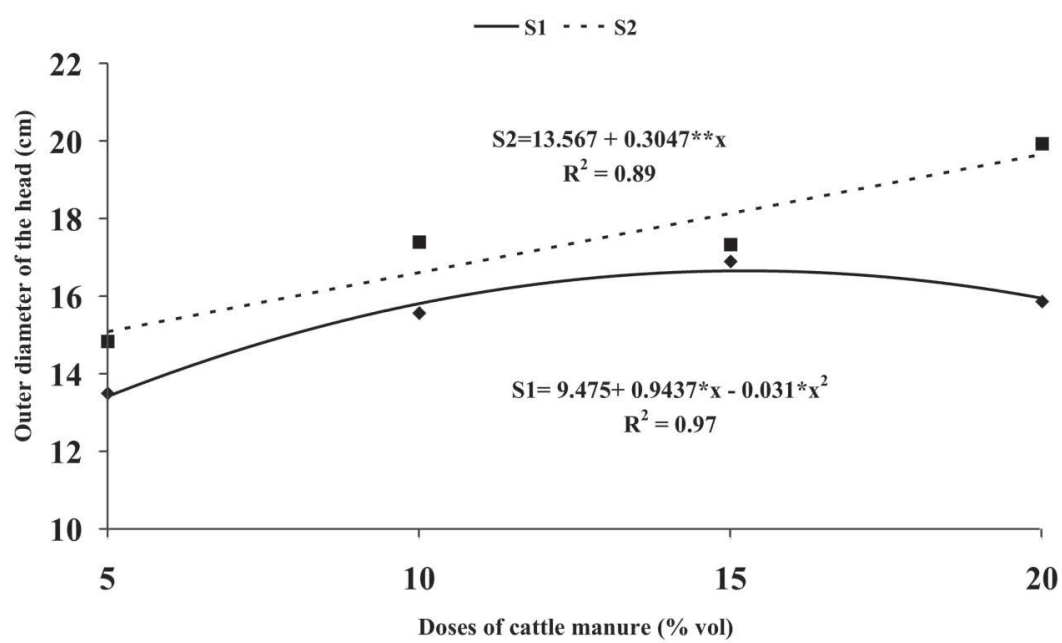

Figura 4. Outer diameter of the head of sunflower var. Embrapa 122-V2000 accordingo to the doses of cattle manure applied on soil (Fluvissol-S1, Haplic Luvisol-S2) $(* \mathrm{P}<0,05 ; * * \mathrm{P}<0,01)$.

Rev. Ceres, Viçosa, v. 60, n.3, p. 397-405, mai/jun, 2013 
obtained with the control (mineral fertilizer), the Dunnett test was used (Table 3). In general, on Fluvissol (Soil 1), the chemical fertilization was better only when compared to the lowest doses of manure (5 and 10\%), except for DEcap with the dose $20 \%$ of manure. For the variable W1000S, the mineral fertilization was not superior to any dose of cattle manure. On Soil 2, for the variables WSP and $\mathrm{EDH}$, the mineral fertilization was better until the 15 and $5 \%$ of manure, respectively. Positive responses to organic fertilization were found by Pereira et al. (2012), when studying cattle manure effects on cotton CNPA $7 \mathrm{H}$ for two years in Paraíba hinterland, and by Severino et al. (2006), when fertilizing castor bean plants with cattle manure.

Considering the little difference in yield components of sunflower, between the use of cattle manure and mineral fertilizer, the cattle manure can replace chemical fertilizers, if it is sufficiently available in the region. Besides of solving nutritional deficiencies in soils, the manure would reduce the costs of sunflower production, constituting an important practice for the sustainability of the soil.

The lowest water consumption $(115.51 \mathrm{~L})$ was observed in plants cultivated in Fluvissol (Solo 1), while the consumption in Haplic Luvisol (Solo 2) was $16.40 \%$ higher $(134.45 \mathrm{~L})$. This difference can be explained by the fact that plants cultivated in Haplic Luvisol, had higher total biomass (Table 4), which confirms the results obtained by Doorenbos \& Pruit (1997), indicating that the increase in the biomass yield is associated with higher consumption of water. It can be observed on Table 4 that, when sunflower plants were fertilized with mineral fertilizer, water consumption in both soils did not differ from the consumption of sunflowers fertilized with manure.

Regarding the efficiency of the water use, a significant effect ( $p<0.01$ ) was only observed on doses of cattle manure (Figure 5). The efficiency of water use increased at a rate of $0.03 \mathrm{~g} \mathrm{~L}^{-1}$ per percentage unit of cattle manure increased, totalizing $1.349 \mathrm{~g} \mathrm{~L}^{-1}$ for $20 \%$ of manure, evidencing, this ways, the beneficial action of the manure, since the plants exposed to higher doses of manure had higher total biomass.

Although there was no significant difference between the treatments manure and mineral fertilizer, the definition of the optimal dose of manure for sunflower, would allow water saving and the improvement of the physical, chemical and biological properties of the soils in Paraíba hinterlands, through the rational use of water and fertilization, resulting in an increase of the productivity for the region, as stated by Pereira et al. (2012).

According to the data of biomass production and water consumption of the sunflower, it can be noticed that the efficiency of the water use, although not

Tabela 3. Number of seeds per plant (NSP), weight of seeds per plant (WSP), weight of 1000 seeds (W1000S) and outer diameter of the head $(\mathrm{EDH})$ of Sunflower according to the doses of manure in soils 1 and 2, compared to the witness chemically fertilized in soil 1 and 2

\begin{tabular}{|c|c|c|c|c|}
\hline \multirow{2}{*}{ Treatment } & NSP & WSP & W1000S & EDH \\
\hline & № & g & g & $\mathbf{c m}$ \\
\hline $05 \%$ of manure soil 1 -test 1 & $-485.67^{*}$ & $-13.40^{*}$ & $-00.07^{\mathrm{ns}}$ & $-05.50^{*}$ \\
\hline $10 \%$ of manure soil 1 -test 1 & $-576.67^{*}$ & $-07.30^{\mathrm{ns}}$ & $-08.70^{\mathrm{ns}}$ & $-03.30^{*}$ \\
\hline $15 \%$ of manure soil 1 -test 1 & $-219.67^{\mathrm{ns}}$ & $-06.97^{\mathrm{ns}}$ & $-03.30^{\mathrm{ns}}$ & $-02.10^{\mathrm{ns}}$ \\
\hline $20 \%$ of manure soil 1 -test 1 & $-312.33^{\mathrm{ns}}$ & $-04.13^{\mathrm{ns}}$ & $-11.00^{\mathrm{ns}}$ & $-03.13^{*}$ \\
\hline $05 \%$ of manure soil 2 -test 2 & $-286.67^{\mathrm{ns}}$ & $-20.67^{*}$ & $-10.70^{\mathrm{ns}}$ & $-04.57^{*}$ \\
\hline $10 \%$ of manure soil 2 -test 2 & $-11.33^{\mathrm{ns}}$ & $-12.53^{*}$ & $-08.70^{\mathrm{ns}}$ & $-02.00^{\mathrm{ns}}$ \\
\hline $15 \%$ of manure soil 2 -test 2 & $-143.33^{\mathrm{ns}}$ & $-12.00^{*}$ & $-05.70^{\mathrm{ns}}$ & $-02.07^{\mathrm{ns}}$ \\
\hline \multirow[t]{2}{*}{$20 \%$ of manure soil 2 -test 2} & $+125.00^{\mathrm{ns}}$ & $+02.97^{\mathrm{ns}}$ & $+00.63^{\mathrm{ns}}$ & $+00.53^{\mathrm{ns}}$ \\
\hline & \multicolumn{4}{|c|}{ Means } \\
\hline Test 1 (chemical fertilizer) & 1405.67 & 30.90 & 18.00 & 19.00 \\
\hline Test 2 (chemical fertilizer) & 1293.33 & 40.27 & 30.70 & 19.40 \\
\hline $05 \%$ of manure soil 1 & 920.00 & 17.50 & 17.30 & 13.50 \\
\hline $10 \%$ of manure soil 1 & 828.33 & 23.60 & 26.70 & 15.57 \\
\hline $15 \%$ of manure soil 1 & 1186.00 & 23.93 & 21.30 & 16.90 \\
\hline $20 \%$ of manure soil 1 & 1093.33 & 26.77 & 29.00 & 15.87 \\
\hline $05 \%$ of manure soil 2 & 1006.67 & 19.60 & 20.00 & 14.83 \\
\hline $10 \%$ of manure soil 2 & 1283.00 & 27.73 & 22.00 & 17.40 \\
\hline $15 \%$ of manure soil 2 & 1150.00 & 28.27 & 25.00 & 17.33 \\
\hline $20 \%$ of manure soil 2 & 1418.33 & 43.24 & 31.33 & 19.93 \\
\hline
\end{tabular}

ns $*=$ not significant and significant at $5 \%$ of probability pelo by Dunnett test $=$ mineral fertilization, - = inferiority of chemical fertilization, $+=$ superiority of organic fertilization, $\mathrm{S}_{1}-$ Fluvissol, $\mathrm{S}_{2}-$ Haplic Luvissol 
Tabela 4. Total dry matter, water consumption (L) and efficiency of the water use (EA) ( $\left.\mathrm{g} \mathrm{L}^{-1}\right)$ on Sunflower 422-V2000 according to the doses of cattle manure on soils 1 and 2, compared to the chemically fertilized control

\begin{tabular}{|c|c|c|c|}
\hline \multirow[t]{2}{*}{ Treatment } & TDM & water consumption & water use efficiency \\
\hline & $\mathbf{g}$ & $\mathbf{L}$ & $\mathrm{gL}^{-1}$ \\
\hline $05 \%$ of manure soil 1 -test 1 & $-56.73^{*}$ & $-11.09^{\mathrm{ns}}$ & $-0.38^{*}$ \\
\hline $10 \%$ of manure soil 1 -test 1 & $-30.80^{*}$ & $-16.70^{\mathrm{ns}}$ & $-0.10^{\text {ns }}$ \\
\hline $15 \%$ of manure soil 1 -test 1 & $+17.45^{\mathrm{ns}}$ & $-04.71^{\mathrm{ns}}$ & $+0.20^{\mathrm{ns}}$ \\
\hline $20 \%$ of manure soil 1 -test 1 & $+07.15^{\mathrm{ns}}$ & $-08.15^{\mathrm{ns}}$ & $+0.15^{\mathrm{ns}}$ \\
\hline $05 \%$ of manure soil 2 -test 2 & $-35.53^{*}$ & $-16.37^{\mathrm{ns}}$ & $-0.15^{*}$ \\
\hline $10 \%$ of manure soil 2 -test 2 & $-02.67^{\mathrm{ns}}$ & $-03.98^{\mathrm{ns}}$ & $+0.01^{\mathrm{ns}}$ \\
\hline $15 \%$ of manure soil 2 -test 2 & $+11.04^{\mathrm{ns}}$ & $-05.25^{\mathrm{ns}}$ & $+0.12^{\mathrm{ns}}$ \\
\hline \multirow[t]{2}{*}{$20 \%$ of manure soil 2 -test 2} & $+26.77^{*}$ & $-03.00^{\mathrm{ns}}$ & $+0.22^{\mathrm{ns}}$ \\
\hline & & Means & \\
\hline Test 1 (chemical fertilizer) & 149.26 & 123.17 & 1.21 \\
\hline Test 2 (chemical fertilizer) & 147.26 & 141.59 & 1.04 \\
\hline $05 \%$ of manure soil 1 & 92.54 & 112.07 & 0.83 \\
\hline $10 \%$ of manure soil 1 & 118.47 & 106.47 & 1.11 \\
\hline $15 \%$ of manure soil 1 & 166.72 & 118.46 & 1.41 \\
\hline $20 \%$ of manure soil 1 & 156.42 & 115.02 & 1.36 \\
\hline $05 \%$ of manure soil 2 & 111.73 & 125.23 & 0.89 \\
\hline $10 \%$ of manure soil 2 & 144.60 & 137.62 & 1.05 \\
\hline $15 \%$ of manure soil 2 & 158.31 & 136.35 & 1.16 \\
\hline $20 \%$ of manure soil 2 & 174.04 & 138.60 & 1.26 \\
\hline
\end{tabular}

ns $*=$ not significant and significant at $5 \%$ of probability pelo by Dunnett test $=$ mineral fertilization, $-=$ inferiority of chemical fertilization, + = superiority of organic fertilization, $\mathrm{S}_{1}-$ Fluvissol, $\mathrm{S}_{2}-$ Haplic Luvissol

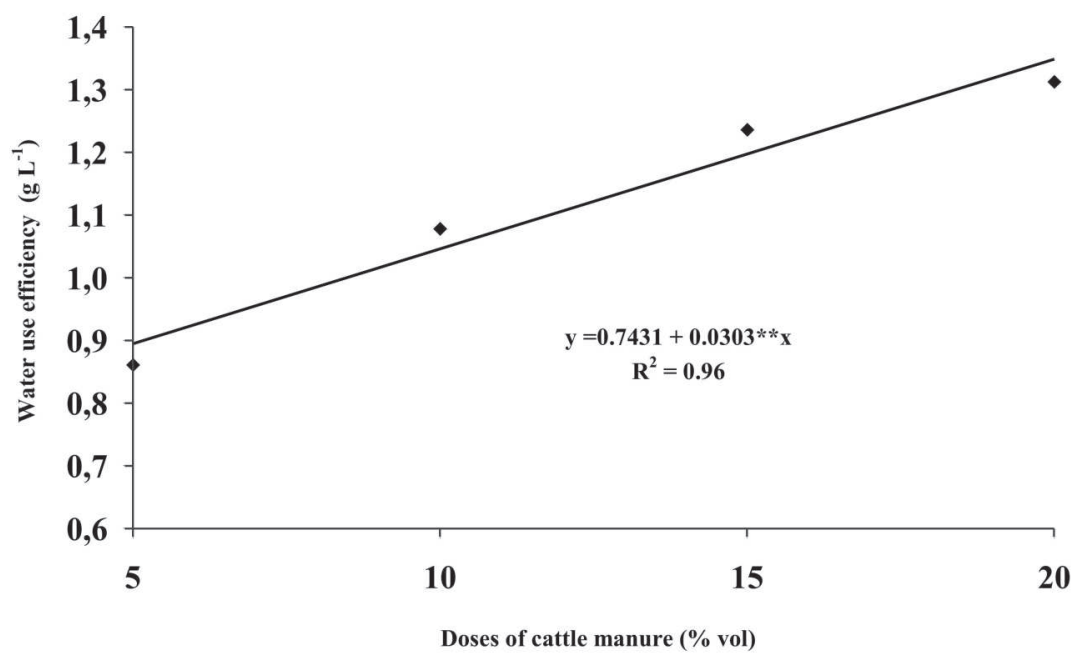

Figura 5. Efficiency of the water use of sunflower var. Embrapa 122-V2000 according to the doses of cattle manure applied on soil $(* * \mathrm{P}<0,01)$

significantly, was increased by the doses of manure in both soils, i.e., sunflower plants showed greater ability to reverse the volume of water consumed in production of dry matter (Table 4).

Except for the treatment with 5\% of manure, there was no significant difference between the mineral and organic fertilization, on efficiency of the water use in sunflower, showing that organic matter is a viable alternative to replace agrochemicals resulting in benefits to the environment (Table 4).

\section{CONCLUSIONS}

The cattle manure increased significantly the values of yield components of sunflower variety Embrapa $122 \mathrm{~V} /$ 2000.

With the exception of the weight of 1000 seeds and the efficiency of water use, the type of soil affected significantly the water consumption and the number and weight of seeds per plant of sunflower. Plants grown in Haplic Luvisol showed better development characteristics. 
The efficiency of the water use by sunflower was significantly increased by cattle manure, leading to think about the viability of the organic matter as a fertilizer, in its effect on the reduction of production costs and at the same time, constitute an important practice for the sustainability of the environment.

\section{REFERENCES}

Albuquerque PEP (2010) Estratégia de manejo de irrigação: exemplos de cálculos. Sete Lagoas, Embrapa. Circular Técnica 136. $25 \mathrm{p}$.

Barker RE, Frank AB \& Berdahl JD (1989) Cultivar and clonal differences for water use efficiency and yield in four forage grasses. Crop Science, 29:58-61.

Bayer C \& Mielniczur J (2008) Macromoléculas e substâncias húmicas. In: Santos GA, Silva LS, Canellas LP \& Camargo FAO (Eds.) Fundamentos da matéria orgânica do solo: Ecossistemas tropicais e subtropicais. Porto Alegre, Metropole. p.7-16.

Biscarro GA, Machado JR, Tosta MS, Mendinça V, Soratto RP \& Carvalho LA (2008) Adubação nitrogenada em cobertura no girassol irrigado nas condições de Cassilândia-MS. Ciência e Agrotecnologia, 32:1366-1373.

Braz MRS \& Rosseto AV (2010) Acúmulo de nutrientes e rendimento de óleo em plantas de girassol influenciados pelo vigor dos aquênios e pela densidade de semeadura. Semina: Ciências Agrárias, 31:1193-1204 (Suplemento, 1).

Castro C \& Farias JRB (2005) Ecofisiologia do girassol. In: Leite RMVB, Brighenti AM \& Castro C (Eds.) Girassol no Brasil. Londrina, Embrapa. p.163-218.

Doorenbos J \& Pruitt WO (1997) Necessidade hídrica das culturas. Campina Grande, UFPB. 204p.

Embrapa (1997) Serviço Nacional de Levantamento e Conservação do Solo. Manual de métodos de análise de solo. 2a Edição, Rio de Janeiro, EMBRAPA/SNLCS. 211p.

Gardner FP, Pearce RB \& Mitchell RL (1985) Physiology of crop plants. Ames, Iowa State University. 321p.

Gomes, PF (2009) Curso de estatística experimental. Piracicaba, FEALQ. 541p.

Joner G, Metz PAM, Arboitte MEZ, Pizzuti AD \& Restle J (2011) Aspectos agronômicos e produtivos dos híbridos de girassol (helianthusannus 1.) Helio 251 e Helio 360. Ciência brasileira, 2:266-273.

Lazzarotto JJ, Roessing AC \& Mello AC (2005) Agronegócio do girassol no mundo e no Brasil. In: Leite R MVBC, Brighenti AM \& Castro C (Eds.) Girassol no Brasil. Londrina, EMBRAPA. p. $15-42$.

Lobo TF \& Grassi Filho H (2007) Níveis de lodo de esgoto na produtividade do girassol. Ciencia Del Suelo e Nutricíon Vegetal, $7: 16-25$.

Menezes RSC \& Oliveira TS (2008) Mudanças na fertilidade de um Neossolo Regolítico após seis anos de adubação orgânica. Engenharia Agrícola e Ambiental, 12:251-257.

Nobre RG, Gheyi HR, Soares FAL, Andrade LO \& Nascimento ECS (2010) Produção do girassol sob diferentes lâminas com efluentes domésticos e adubação orgânica. Engenharia Agrícola e Ambiental, 14:747-754.

Pearson C, Cornish K, Mcmahaan CM, Rath DJ, Bricht JL \& Fleet JEV (2010) Agronomic and natural rubber characteristics of sunflower as a rubber-producing plant. Industrial Crops and Products, 31:481-491.
Pereira JR, Araújo WP, Ferreira MMM, Lima FV, Araújo VL \& Silva NB (2012) Doses de esterco bovino nas características agronômicas e de fibras do algodoeiro herbáceo BRS Rubi. Revista Agro@mbiente,6:195-204.

Ribeiro AT, Guimarães PTG \& Alvarez VH (1999) Recomendação para o uso de corretivos e fertilizantes em Minas Gerais. $5^{a}$ Aproximação Viçosa, CFSEMG. 359p.

SAEG (2003) Sistemas para Análises Estatísticas e Genética. Versão 5.0. Viçosa, Fundação Artur Bernardes, UFV.

Sampaio IBM (1998) Estatística aplicada à experimentação animal. Belo Horizonte, Fundação de Ensino e Pesquisa em Medicina Veterinária e Zootecnia. 221p.

Santos Júnior JA, Gheyi HR, Dias NS, Soares FAL \& Nobre RG (2011) Doses de boro e água residuária na produção do girassol. Ciência Agronômica, 42:857-864.

Severino LS, Ferreira, GB, Moraes CRA, Gondim TMS, Cardoso GD, Viriato JR \& Beltrão NEM (2006) Produtividade e crescimento da mamoneira em resposta à adubação orgânica e mineral. Pesquisa Agropecuária Brasileira, 41:879-882.

Silva AG, Pires R, Morães EB, Oliveira ACB \& Carvalho CGP (2009) Desempenho de híbridos de girassol em espaçamentos reduzidos. Semina: Ciências Agrárias, 30:31-38.

Silva ARA, Bezerra FML, Sousa CM, Pereira Filho JV \& Freitas CAS (2011) Desempenho de cultivares de girassol sob diferentes lâminas de irrigação no Vale do Curu, CE. Ciência Agronômica, 42:57-64.

Silva MLOE, Farias MA, Morais AR, Andrade GP \& Lima EMC (2007) Crescimento e produtividade do girassol cultivado na entressafra com diferentes lâminas de água. Engenharia Agrícola e Ambiental, 11:482-488.

Vazin F, Hassanzadehdelouei M \& Kheradmand M (2011) Effect of Defoliation and Fe and Mn Spraying on Quality and Quantity Characteristics of Sunflower (Helianthus annuusL.). Notula e Scientia Biologicae, 3:113-119. 